As a critic, I am most alarmed at Mr. Chaves's introduction of that old-fashioned, unknowable phantom (a ghost laid long ago)-the "poet's intention," for which read "translator's self-serving guess." This handy marionette permits (indeed, it seems, welcomes) any ad boc rearrangement of the words of the text to justify any reading whatsoever-a dislocation madly justified as an "intended" ambiguity.

Under the circumstances, my own, authentic reading of the battered couplet, so boldly interpreted on my behalf, is reasonably to be expected. (I reject the brazen attribution to me of an extension of the category "causative" to all comparable verb + noun constructions. I prefer more often a mildly transitive form, for which there is abundant precedent in Chinese prose. The proper terminology of Chinese grammar, divorced from the traditional categories of Indo-European, has yet to be precisely formulated by competent historical linguists.) But now, without hazarding a definitive version, I imagine that the facts of grammar and good sense, as exploited by the poet's imagination, permit only one reading of the couplet, more or less as follows:

The height of the bamboos gives voice to halcyons;

The seclusion of the sands allows dancing to $k^{\prime} u n$-fowl.

Commentary:

The high bamboo thicket emits bird calls-identifiable as those of unseen halcyon kingfishers;

The out-of-the-wayness of the sands provides a private arena ("lek") for posturing $k^{\prime} u n$ birds.

EDWARD H. SCHAFER

\title{
The Buddhist Conception of Kingship and Its Historical Manifestations: A Reply to Spiro
}

This is not a lion's roaring,

Nor a tiger's, nor a panther's;

Dressed in a lion's skin,

'Tis a wretched ass that roars!

\begin{abstract}
A Jātaka story gives this characterization of the ass in the lion's skin, a characterA ization that is a perfect contrast to a heroic figure in Buddhism, the cakkavatti, "the lion-hearted man roaring a lion's roar."

In his review (JAS, XXXVI, Aug. 1977, pp. 789-791) of my book World Conqueror and World Renouncer (hereafter referred to as $W C$ ), Spiro, for his own polemical purposes and with a resolute intention to discredit it, by and large narrows the evaluation of a complex and many-stranded-work to a single issue: the canonical conception of kingship in early Buddhism and its impact on the Buddhist kingdoms of South and Southeast Asia. The complete education of Spiro requires more space than I can claim here, and since I am composing a long essay for that purpose, I shall confine myself here to some of Spiro's grosser errors and misrepresentations.
\end{abstract}




\section{The canonical conception of kingship}

On the question of the canonical conception of kingship I shall limit myself to these few points:

(I) The thesis that a conception of kingship was an integral feature of early Buddhism is neither idiosyncratic nor unique. Among the scholars who have dealt with this theme are to be counted Paul Mus, Ananda Coomaraswamy, E. Sarkisyanz, U. N. Ghoshal, E. G. Gokhale, and Frank Reynolds. ${ }^{1}$ If Spiro thinks my thesis is misguided, I find myself in good company.

(2) There is incontrovertible evidence that "in Asoka's time the formation of the canon had been practically completed"; it is remarkable that "the name of Asoka, who is praised in all the Buddhist orders, has never been mentioned in the canon"; ${ }^{2}$ it is therefore a valid conclusion that if there are formulations of a political nature in the Pali canon that predate Asoka, then Max Weber's assertion-that "Ancient Buddhism was a specifically unpolitical and anti-political status religion" and that it was under Asoka's reign that "for the first time in Buddhism, the beginnings of a political theory emerge"- -will have to be reconsidered. ${ }^{3}$

(3) I affirm that a conception of kingship of the type described in WC is contained in the Pali canon, and reiterate that there are many references in many parts of the canon to kingship and kings which show that the Buddhist canonists were neither unaware of Brahmanical formulations on "the kshatriya science" nor uninterested in formulating their own attitudes to rulers. I shall document the references in my longer essay; here let me say that I consider that it is primarily in the Digha Nikaya (The Book of Long Sayings) and the Anguttara Nikaya (The Book of Gradual Sayings) that we can discern the contours of a coherent conception of kingship, which finds supplementary support in the Jatakas. I would remind Spiro that the strophes or verses of the Jaatakas (but not the prose narratives) are considered to be part of the Pali canon.

(4) Spiro dismisses the Aggañna Sutta (the sutta "pertaining to beginnings," sometimes glossed as a "book of genesis") as a "myth," an obtuse remark when we consider its repeated appearance in works on Indian political thought, in Buddhist literature throughout the ages, and its invocation in popular thought right up to modern times to explain and legitimate certain social institutions and legal codes.

The Buddhist "contractual theory" of kingship (as it is often referred to) rarely fails to have a prominent place in discussions on Indian political ideas. Ghoshal for instance called it "the most original contribution of the early Buddhist canonists to the store of our ancient social and political ideas," ${ }^{4}$ and Dumont ${ }^{5}$ in a recent authoritative essay discussed the implications of the theory from the perspective of his view of the world renouncer as being outside the caste society and the only true individual in the Hindu social universe.

Apart from its challenge to the Vèdic social order, the book of genesis has a

\footnotetext{
1 The relevant writings of these authors are cited in my book, except Ananda Coomaraswamy, Spiritual Autbority and Temporal Power in the Indian Theory of Government, (New Haven: American Oriental Series [22], 1942).

${ }^{2}$ See Wilhelm Geiger, Pali Literature and Language, Authorized English Trans. by B. Ghosh, (Calcutta: University of Calcutta, I 956), pp. 9-1 3 .

${ }^{3}$ Max Weber, The Religion of India (Glencoe,
}

Ill.: The Free Press, 1958), pp. 206, 237-238

4 U. N. Ghoshal, A History of Indian Political Ideas (Bombay: Oxford Univ. Press, 1959), Chapter IV; another example is A. L. Basham, The Wonder that was India (London: Sidgwick and Jackson, 1954), pp. 82-83.

${ }^{5}$ Louis Dumont, "The conception of kingship in Ancient India," Contributions to Indian Sociology, V (196I). 
distinguished place in Buddhist post-canonical texts, in which the fact of Mahāsammata's being "the great elect" is linked up with other canonical formulations of "the righteous king" (dharmaräja), and "universal king" (cakkavatti); moreover Mahāsammata is declared to have been a bodhisatta, the first ancestor in the royal line to which the Buddha belonged as a Sakyan, and, indeed, a previous incarnation of the Buddha himself. Three strategic textual examples are: Vasubandhu's great Sarvastivàdin cosmological cum doctrinal treatise, Abhidharmakösa; Buddhaghosa's Theravādin classic, Visuddbimagga; and that great collection of traditions and legends pertaining to the Buddha, the Mabavastu (a text of the Lokottaravādins).

Finally here are examples of how the canonical account of first kingship still acts in our own times as a charter. I have already in WC stated how the Mon-Pagan and Thai legal codes find their sacred authority in Mahāsammata (and his sage Manu) as their first instituter. ${ }^{6}$ In Sri Lanka the traditional legal treatise Niti-Nighanduwa ${ }^{7}$ also finds its authority in Mahãsammata; moreover the Sinhalese peasantry hold Mahāsammata to have been the designer of their caste rankings and occupations. ${ }^{8}$

(5) Again, to Spiro's dismissive statement that there is only one myth ${ }^{9}$ of the cakkavatti, I reply that there is a wealth of textual references that indicate a canonical concern with the cakkavatti conception, ${ }^{10}$ and that in the single most important text, the Digha Nikaya, there are six suttas in which the cakkavatti appears as an integral component, and that in most of them there is an explicit comparison between the two great men, the Buddha and the cakkavatti. Why are these conspicuous comparisons made and why the numerous juxtapositions?

Two of the long suttas-the Cakkavatti-Sỉbanäda and the Mabäsudassana Suttas-are in their entirety devoted to the careers of the cakkavatti (Spiro seems unaware that the first sutta contains a crucial millenarian prophecy to which I shall advert later). While three others-the Lakbabana, the Mabäpadana, and the Ambatța Suttas-explicitly refer to the 32 bodily marks of the mabäpurisa or give paradigmatic descriptions of them, it is to one other sutta, the Mabaparinibbana Sutta that I want to direct my attention. Because, as the longest and probably the most quintessential sutta in the entire canon, it is a vital text to all Buddhist schools, it is preserved for us in six different versions, ${ }^{11}$ and it contains one supremely pregnant

${ }^{6}$ See WC, pp. 93-95; and R. Lingat, The Classical Law of India (Berkeley: Univ. of California Press, 1973), p. 267; "Evolution of the Conception of Law in Burma and Siam," Journal of the Siam Society XXXVIII (1950).

"Niti-Nighanduwa or the Vocabulary of Law as it Existed in the Days of the Kandyan Kingdom, trans. by C. J. R. LeMesurier and T. B. Panabokke, I 880 .

${ }^{8}$ Ralph Pieris, Sinhalese Social Organization, The Kandyan Period (Colombo: Ceylon Univ. Press, I956), p. I 80 .

"Spiro uses the word "myth" in a deprecatory and dismissive sense, since myth is seen as incapable of contributing to a conception of kingship. Spiro is entitled to hold his impoverished notions of myth, but the point is that the texts Spiro labels "myth" are not so labelled by the canon, and are equally canonical as any other sutta, and by no means unique in having legendary and cosmologi- cal features. It is the anthropologist's business first and foremost to try and understand how such canonical materials were understood and acted upon by Buddhists, not to arbitrarily impose labels.

Further, I cannot suppress the temptation to remark that after all the Oedipus story is also only one myth, yet a myth reiterated in many versions, and while being only a myth it has had important significance in Western civilization, not the least important of which is its place in Freudian theory, which Spiro accepts as a "science" and whose "application" cross-culturally he considers his avowed mission.

${ }^{10}$ Again, I shall give the references in my longer essay.

1 See André Bareau, "The Superhuman Personality of the Buddha and its Symbolism in the Mahäparinirvānasütra of the Dharmaguptaka" in Myth and Symbols, ed. J. M. Kitagawa and C. H. Long (Chicago: Univ. of Chicago Press, 1971). 
juxtaposition of the two great men, which no student of Buddhism can afford to miss, because it contains the seeds of later religious realizations.

The sutta reports that the Buddha wished his remains to be treated with all the honors due to a cakkavatti and that he reminded Ananda that the wattle and daub settlement of Kusinara is the chosen location of his death because he had in a previous existence ruled over this same place, then a glorious city, as the cakkavatti Mahāsudassana.

Now the Mabäprinibbäna Sutta occupies a central place in my book because it presents in quick episodic succession the multiple strands of early Buddhism as a simultaneous totality - the norms the community of bhikkbus should observe, the fruits accruing to the meditator, the entrusting to laymen of the Buddha's relics and their enshrinement in dàgabas, the sanctioning of merit-making pilgrimages, the loss of reputation and other consequences to laymen resulting from wrong actions, etc. Why is Spiro wedded to the notion that the essence of early Buddhism is the nibbanna quest, and that other strands, such as the kammatic, are deviations and shifts (a thesis blandly proposed without recourse to any historical evidence)? Why cannot Spiro grasp the simple idea that early Buddhist thought could without contradiction theorize on the one hand how the world is constituted and objectified, and on the other, how it can be dissolved and transcended; how, on the one hand, the householder can be adjured to lead a moral existence in this world, with the orderly maintenance of that world being assigned to the righteous king, while on the other the bbikkbu can be instructed in the ethic of non-action and in the method of renunciation as discovered and taught by the Buddha?

Why does Spiro not comprehend that the Buddhist canonists showed great concern to develop the cakkavatti image beyond the limits of their brahman rivals, because there was a philosophical and doctrinal imperative to match the conception of the Buddha as the universal sage (sakyamuni) and world renouncer with the personage of the universal ruler (cakkavatti), a matching both complementary and hierarchical?

What I consider to be Spiro's failure is roored in a fundamental difference between our understandings of the scope, ramifications and potentialities of the canon. I hold (with many other scholars) that Buddhist traditions from the earliest times have contained three strands that have always been interwoven: the Buddhalogical traditions surrounding the Buddha's person, his career, and his remembrance of his previous lives; the cosmological contents which stem from meditative experiences and find representation both as inner states of consciousness and as cosmic levels of reality; and the nibbänic philosophy with its insight into co-dependent origination revealing the path of release from an ultimately illusory worldly existence. All three strands are embedded in the canonical materials and provide the yeast for later elaborations.

\section{A colossal misreading}

Spiro fails to comprehend what another reviewer ${ }^{12}$ has grasped as a critical point in my book: that while the canonical theorists of early Buddhism postulated a grand conception of kingship as the primary ordering principle of society, at the same time they failed to produce a systematized and differentiated code of administration (or

\footnotetext{
${ }^{12}$ Edmund Leach's review of WC in The Times Literary Supplement, I4 Jan. 1977.
} 
government) and that some of the major flexibilities (and instabilities) of actual Buddhist polities are rooted in this space. This lack was partly filled by the employment of brahmans as court functionaries, teachers of statecraft and interpreters of law, ${ }^{13}$ and, as alluded to earlier, by the codification of local customs as versions of dharmaśástra produced by a Manu serving the superior Buddhist king, Mahāsammata. An important comparative conclusion is drawn in the book between the encompassing dharma doctrine of the Buddhist polity which is not rigidly interlocked with particular social codes and the case of Islam where religious doctrinal revivalism is tied to the observance of specified traditional social codes (WC pp. 430-43I).

The point of all this is that a conception of kingship does not necessarily entail a systematic theory of government or administration. I maintain contra Spiro that the right and sensible question to ask is not whether early (and subsequent) Buddhism had a conception of kingship-for that it patently did-but what are the semantic features of this conception and what meanings and consequences did it have for the lives of the people who believed in it and lived by it. In other words, the correct comparative question is: What is "kingship" all about in the societies where it finds expression? Thus the grounding of the legitimacy of the Buddhist "righteous ruler" and "king of kings" in a culturally distinctive notion of dharma does not have the same substantive implications for the institutionalization of those features that a western conception of "rational politics" or a "science of politics" automatically demands. In ideological terms, the traditional Buddhist ruler is no "constitutional ruler;" his actions are not periodically affirmed by the "consent" of the governed or the allegiance of those who "share" power with him. There are no "natural rights" grounded in human nature as such. The Buddhist formulation is that the king is the upholder of dharma, which exists as an eternal entity, and a correlative of its enduring and invariant nature is that individual kings represent it variably as human actors in accordance with their karma, and thereby experience different degrees of success in their reigns. Kingship quintessentially represents and "creates" worldly order and its pulsations through the cosmic rites assigned to it; the king's apical position in society by definition endows him with great merit which he shares and distributes to his subjects. In these senses, the ideology of kingship provides the basis for ordering this world of lay actors who belong to the käma realm of desire, while the higher conception of the Buddha and his teachings provides the basis for liberation for those who wish to transcend it.

\section{Historical manifestations}

With a cocky flourish Spiro asks how can it be claimed that the Buddhists of Southeast Asia identified their kings with the cakkavatti (see WC p. 482) or that the grand imperial conception of cakkavatti opened the way for Buddhist monarchs to found world empires (see WC p. 52), when "such contentions are neither canonical-

${ }^{13}$ See $W C$, pp. 52-53 and pp. 93-95. One may also add to this the lack of comprehensive lay social codes that are directly derived from the canonical doctrines, a point on which I agree with Max Weber. But note that kings attempted to find legitimacy for the codes in the canon, as for example, Rama I when he ordered a revised compilation of the Siamese Law Code (WC, p. I87). In addition to my citation of Bechert regarding the use of Kauțilya's Arthaśästra (or some version of it) for the instruction of princes in Sri Lanka and Burma, additional confirmation is to be found for Sri Lanka in W. Geiger, Culture of Ceylon in Medieval Times (Wiesbaden: Otto Harrassowitz, I 960), p. I I9, and for Ayuthaya of the fifteenth century in Charnvit Kasetsiri, The Rise of Ayudbya (London: Oxford Univ. Press, 1976). 
ly warranted, nor, so far as I know, are they subscribed to by Buddhist actors, past or present," "since the kings and rulers whom they knew (and know) were typically rapacious and oppressive...."

Not only does what Spiro knows not go far, but also his sweeping contempt for the careers of Buddhist kings does, to say the least, damage to our discipline in the Third World. Spiro ought to know that by the standards of the societies concerned (and by those of several eminent Western scholars as well) there have been oppressive as well as benevolent kings, that the great kings have been to varying degrees both oppressive and meritorious in different aspects of their activities or at different stages of their careers. He also ought to know that while the Burmese and the Thai on the one hand described their rulers as "eaters of the land," they also looked upon them as the greatest of merit-makers, a point of view that ideologically overshadowed all negative judgments. ${ }^{14}$

How comical that Spiro should not know that several Burmese kings have claimed to be cakkavatti (some of them concurrently assuming bodbisattva and dharmaräja titles)-for instance, Tabin Shwehti (I 53 I-I 550), Alaungpaya (1752-1760), Bodawpaya ( $178 \mathrm{I}-18 \mathrm{I} 9$ ). All the more remarkable when Sarkisyanz has given us a meticulous documentation of "the cakkavatti ideal as a factor in the expansion and fall of the Burmese Empire."15

A standard history of Sri Lanka routinely records: "The title cakravartin (universal emperor) for kings came into vogue in the Polonnaru period. ${ }^{16}$ It first appears in a contemporary document with reference to Jayabāhu I and is given to Gajabāhu II in that monarch's Kapuruvädu Oya inscription. The [Cülavamsa] chronicle uses the title with reference to Parakrama Bāhu I; it was a regular epithet of Nissamkamalla and his successors." 17 The quintessential Sinhalese example is Nissamkamalla (I 187-I 196) whose inscriptions throw light on how Sinhalese kings represented their careers while claiming to be cakkavatti. The Polonnaruva Hatadāge Portico Slab Inscription and the Prìti-Dānaka Mandapa Rock Inscription, for example, document Nissamkamalla's claim to be of cakkavatti and solar lineage, and they relate that having first embarked on empire building and having no enemy kings to defeat in South India, he turned to "conquering" the next world by acts of merit and by destroying the enemies within him, namely the evil passions. What better evidence can I provide in vindication of my claim that the Asokan career was a model for Buddhist cakkavatti kings? ${ }^{18}$ Thus the answer to how Buddhist kings commonly

\begin{abstract}
14 Thus Akin Rabibhadana (Change and Persistence in Thai Society, ed. G. W. Skinner and A. T. Kirsch [Ithaca: Cornell University Press, 1975], p. I03) writes of the Bangkok period that "Thai kingship was sacred because it represented the dharma, the moral order of society" and develops why it was believed that in the Thai king inhered infinite bun (merit) and infinite sak (power, energy)." Similarly Michael Aung Thwin (Explorations in Early Buddhist Asian History: The Origins of Southeast Asian Statecraft, ed. Kenneth R. Hall and John K. Whitmore [Michigan Papers on South and Southeast Asia, No. II, 1976]) says of the Pagan King that he was "the person who had most merit to share with everyone," a characterization that links up with the king's claim to be a bodhisatia.
\end{abstract}

C. F. Keyes in "Millenialism, Theravāda Bud- dhism, and Thai Society,"JAS, xxxvI (1977), also refers to the idea that the king is the most meritorious person in the kingdom, an idea that persists to this day.

${ }^{15}$ E. Sarkisyanz, Buddhist Backgrounds to the Burmese Revolution (The Hague: M. Nijhoff, 1965), Chapter Xv.

${ }^{16}$ That is, from the eleventh century onwards.

${ }^{17}$ History of Ceylon, ed. in charge, H. C. Ray, Vol. I, Part II (Colombo: Ceylon University Press 1 960), p. 57. For fuller evidence see Epigraphia Zeylanica II and III.

${ }^{18}$ Historical cakkavatti kings also defended their attacks on neighboring kings as acts of dharma-vijaya, the Asokan concept of non-violent conquest by dharma which they reinterpreted as acts of warlike conquest to defend and preserve Buddhism. Aniruddha of Pagan justified his fa- 
resolved the dilemma of violating the ethic of non-violence while claiming to be cakkavatti was to stretch the dilemma over a sequence of life stages: to make the imperial conquests first and later turn to piety. This resolution is analagous to a common fact of anthropological reporting; the Buddhist peasant breaks the five precepts including that of not taking life in the prime of his or her adult life and in old age becomes a pious upasaka or upasika.

If Spiro is unaware of the above examples, he is unlikely to know of the Thai exemplar-Phya Lithai, who as heir apparent to the Sukhothai throne, composed in I 345 the great cosmological treatise, the Traibhümikatba ${ }^{19}$ (the Sermon on The Worlds) with a section on the cakkavatti (an elaboration based on canonical materials) as its centerpiece in the description of the realm of humans, followed by another section on Asoka who is described as a "lesser cakkavatti." 20 This treatise is one of the texts that Thai kings frequently had copied and revised, together with the Pali canonical texts, when they sponsored great revivals of religion. Lithai, who later as king successfully revived Sukhothai power and territory, took the title of Mahādhammarāja, directly associated himself with the Bodhisattva ideal, and even with the figure of a fully realized Buddha. No doubt all this must come as a shock to Spiro's quixotic fantasy that he is the guardian of true Buddhism.

Spiro asks how if he is a mabäpurisa (which he wrongly glosses as "semi-divine human being" ${ }^{21}$ ), who like the Buddha is known by the 32 conspicious bodily marks, can the cakkavatti provide a precedent for human emulation? I grant that the cakkavatti has certain superhuman features, but Spiro's Judaeo-Christian blinkers focus his vision on an unbridgeable chasm between the "divine" and the "human" whereas in Buddhist cosmology the gods of the six levels immediately above the human realm (including the gods of the Tusita heaven of which the next Buddha Mettaya is one, while he awaits his future rebirth among men) together with humans, asuras, animals, hungry ghosts, and beings of hell, belong to the same senseand-form-and-desire-ridden käma world. The käma world (like the orher rüpa and arüpa worlds as well) is a hierarchy of beings placed according to their kammic achievements, and these beings are constituted of different proportions of the same elements.

I cannot emphasize enough that, whatever his extraordinary attributes, the Pali canon presents the cakkavatti as capable of being realized in the human realm, bis locus being the soutbern continent of Jambudvipa. A part from the precedent that the Buddha had been a cakkavatti in Jambudvipa in his previous lives, and the statement that the celestial wheel will appear of its own accord when a king's righteous rule deserves it, there is the important millenarian prophecy made at the end of the Cakkavatti Sibanäda Sutta that after a period of disorder there will appear in Ketumati (Benares) a wheel-turning king called Sankha, and at that time will appear in the world the next Buddha, Mettaya. This prophecy of the appearance together of the two great men, who will initiate a new age and cycle has been a stimulus to certain

mous attack on Thaton as dharma vijaya. In this guise the concept of dharma-vijaya bears some resemblance to the Islamic notion of "holy war."

${ }^{19}$ There exists a French translation of this work: G. Coedès and C. Archaimbault, Les Trois Mondes, Vol. LxxxIx, Publications de l'Ecole Française d'Extrême-Orient, Paris, 1 973. An English translation by Frank and Mani Reynolds titled The
Three Worlds of Phrā Ruang is in press, and I have consulted it.

${ }^{20}$ This appellation is foreshadowed in the Divyävadäna (one of the earliest non-canonical works, composed in "hybrid Sanskrit") which refers to Asoka as bälacakravartiräjya. I am grateful to Professor Nagatomi for this reference.

${ }^{21}$ Mabäpurisa is "great man." 
kinds of religio-political millenarian movements in Southeast Asia, of which there is ample documentation. ${ }^{22}$

It is in the context of the doctrine of a hierarchy of beings (with the lesser and grosser materializations aspiring to make contact with the higher), ${ }^{23}$ and the millenarian hope of realizing the ideal realm of the cakkavatti, that the 32 marks of the great man must be placed. While it is the Buddha and the cakkavatti who have the full complement of marks, it is a commonplace in the Buddhist (and Hindu) world that all human beings have markings of various felicity. Thus for example there was great preoccupation among royalty with bodily marks (lakkbananni), ${ }^{24}$ and there is a widespread resort to palmistry, astrology, and other forms of reading auguries in South and Southeast Asia.

\section{Cheap tricks}

To conclude with some distasteful but necessary deodorizing: Spiro writes that "Tambiah finds it easy to view contemporary Thai monks as entirely satisfactory exemplars of the true Sangha." This is a mischievous fabrication, and I suggest that such resort is an overreaction on Spiro's part to his own misplaced outrage at the fact of Thai monks participating in community development. ${ }^{25}$ After extended and careful documentation of many Thai monks' motivations to become "professional" monks, among which the acquisition of education looms large, and of Thai monks' present day activist ideological orientations, when I remarked that these ambitions towards activistic roles in society are "understandable," I merely meant that given such motivations their responses are to be expected. Spiro chooses to misread and distort this remark as my condoning of such orientations as being in line with the monk's nibbanic quest.

These reactions are symptomatic of a divide separating Spiro from me. Spiro, obsessed with the notion of early Buddhism as being solely concerned with nibbäna, not only sees other Buddhist manifestations as deviations, but wants constantly to measure every historical manifestation against his conception of the pure ideal, preoccupations of a theological and evangelical character. I, in contrast, focus on how the Buddhist actors through time represent themselves and their actions, and the continuities and transformations that are discernible in these responses, preoccupations of an anthropological and historical nature. And I insist that within the armature of early Buddhism that I have delineated in my book it is more productive to see the nexus between Buddhist doctrinal ideas and historical actualities in terms

\footnotetext{
${ }^{22}$ For discussions of how this prophecy has taken root in Burmese popular thought and action (including its relevance for the Saya San rebellion in the I930s) see E. M. Mendelson, "A Messianic Buddhist Association in Upper Burma," Bulletin of the London Scbool of Oriental and African Studies, XXIV ( 3,1961 ); and "Observations on a Tour in the Region of Mount Popa, Central Burma," France-Asie Extrait du No. 179 (1963); also see on Burma Sarkisyanz, n. I 5 above, Chapter XV.

Concerning the millenarian implications of Metteya's coming for Sri Lanka, see Kitsiri Malalgoda, "Millenialism in Relation to Buddhism," Comparative Studies in Society and History XII (4, 1970).

For Thailand, see C. F. Keyes' informative essay "Millenialism, Theravāda Buddhism ..." n. I 4 above, especially on the millenial uprising in the
}

Northeast at the turn of this century.

${ }^{23}$ See Edward Conze, Buddbist Thought in India (Ann Arbor: Univ. of Michigan Press, 1970), pp. 24-25, for Buddhist doctrines on degrees of reality and hierarchy of beings.

${ }^{24}$ See Wilhelm Geiger, Culture of Ceylon in Medieval Times, n. I 3 above, pp. I I3-1 I4, on the preoccupations of the Sinhalese royalty of medieval times with auspicious markings. One illustrious example was the bodily marks on a princess who it was prophesied would give birth to a mighty ruler over the whole of Jambudvipa; she was the mother of Parakrama Bāhu I, the most illustrious of the Polonnaruva kings.

${ }^{25}$ See Melford E. Spiro, Buddbism and Society (New York: Harper \& Row, 1970), pp. 288, for an expression of this attitude. 
of Weber's concept of "elective affinity," a perspective that allows us to see events as "becoming," and social totalities as dynamic formations.

Spiro doesn't like my version of dialectical tensions, contradictions and complementarities as I see them over time in the thought and action of Buddhist actors. He lampoons them by resorting to the trick of attributing my discussion of them, as they relate to different periods of time or to different pulsations in the same society and to different countries faced with dissimilar circumstances, to a single "group of actors." This is tantamount to my first describing Spiro's representation of the Burmese in these terms: they practice two religions, animism and Buddhism, which exist in tension and conflict and are "opposite orientations to the world";26 they practice funeral rituals in which "various traditions, pre-Buddhist, Buddhist, postBuddhist, and anti-Buddhist have been joined ... and all are observed simultaneously",27 their monks are distinguished from non-monks by "dependency, narcissism, and emotional timidity" ${ }^{28}$ which allow them "to regress and reenact the role appropriate to that infantile period," 29 etc. Then, to my asking whether this account sounds as if the Burmese Sangha and Burmese society comprise one vast psychiatric ward, and/or whether the author of this account suffers from Portnoy's complaint, and is impaled on the horns of Talmudic absolutism and psychoanalytical reductionism (a dilemma of his own devising).

Harvard University

S. J. TAmbiaH

\section{Reply to Professor Tambiah}

Although I am grateful to Professor Tambiah for his vigorous attempts to save me from my ignorance, inasmuch as none of these attempts confronts my basic criticisms, I will stand by everything I wrote in my review. Since the Editor requested that my reply be brief, I shall confine my remarks to Tambiah's major points. I refrain from considering other issues, such as the question of whether a myth of the origin of kingship (the myth of the Mahassammata) can be said to be a theory of government, not only because this depends on the meaning of "theory" (a discussion which would take us far afield), but also because Tambiah's long lecture on the subject is beside the point since my criticism of his thesis of the relationship between canonical Buddhism and political action in Southeast Asia dealt with his treatment of the cakkavatti, not of the Mabassammata. As for the other issues raised by Tambiah, I would ask the readers who might be interested in this dispute to judge the validity of Tambiah's charges by comparing them with my review.

1. Historical kings and the cakkavatti. I might observe, before entering this discussion, that my review concentrated on this issue not for my insidious "polemical purposes" (as Tambiah contends), but because of editorial constraints. My original manuscript, twice the length of the published review, dealt with all the issues raised in the book. Since it was returned by the Editor with instructions to remain

\footnotetext{
${ }^{26}$ Melford E. Spiro, Burmese Supernaturalism (Englewood Cliffs, N.J.: Prentice-Hall, 1967), pp. 250, 257.
}

\footnotetext{
${ }^{27}$ Buddbism and Society, n. 25 above, p. 253.

${ }^{28}$ Ibid., p. 338.

${ }^{29}$ Ibid., p. 342 .
} 